\title{
The Causes of Late Coming among High School Students in Soshanguve, Pretoria, South Africa
}

\author{
Simeon Maile ${ }^{1 *}$, Mary Motolani Olowoyo ${ }^{1}$ \\ 1 Tshwane University of Technology, SOUTH AFRICA
}

*Corresponding Author: mailes@tut.ac.za

Citation: Maile, S. and Olowoyo M.M. (2017). The Causes of Late Coming among High School Students in Soshanguve, Pretoria, South Africa. Pedagogical Research, 2(2), 04. https://doi.org/10.20897/pr/80951

Published: December 8, 2017

\begin{abstract}
Late coming to school has become a major problem in many schools, particularly township schools with serious consequences. Current research has demonstrated that many schools in South Africa are performing badly due to inefficient use of the teaching and learning time. In this article, we argue that while major administrative interventions are undertaken to improve the quality of learning and teaching, it seems that very little attention is paid to late-coming. Late-coming has become a cancer that saps away big interventions and strays the performance of selected township schools in a different direction. The purpose of this research is to investigate the causes of late-coming among high school students in selected secondary schools of Shoshanguve. A qualitative approach was used to draw data from high school students in selected secondary schools of Shoshanguve. The findings reveal that late-coming is common among learners in selected secondary schools of Shoshanguve. It happens every day for varying reasons. We recommended practical solutions ranging from administrative improvement to learner behavioural change.
\end{abstract}

Keywords: late-coming, punctuality, absenteeism, progression, performance, employment

\section{INTRODUCTION}

Late coming to school is one of the major problems that have plagued many schools; there is hardly any school that is spared from this problem. The impact of this great menace cannot be over emphasized, as it has contributed immensely in a negative way to the academic achievement of learners and the functioning of the school (Okpupara and Chuwuone, 2007).

A school is primarily an established institution that aims to educate learners (Oxford Advanced Learners Dictionary, 2010). It is designed with the purpose of bringing children from different families together under one roof (the classroom) for the purpose of teaching and learning under the direction of teachers. One of the important traits entering into a successful person's character is the habit of punctuality (Phurutse, 2005). Effective teaching and learning cannot take place without the coming together of the teacher and the learners (Oghuvbu, 2012). A learner that is not regular in school, faces learning problems resulting from late - coming to school such as, truancy, and inability to read and not consulting with the teacher (Onouwodeke, 1995).

Lateness can be viewed as an outcome of laxity or system breakdown (Peretemode, 1991). Lateness is a function of time and as such time is usually used as the criteria for determining lateness. Late coming violates the principle of punctuality and if not checked at the onset, may become a habit with the individual involved and may have negative consequences (Breeze et al., 2010).

The importance of education is increasing and is regarded highly. The societies of the past are on the front rank of the world civilization on account of education, this educational system may be seriously hampered as a result of late-coming especially in high schools. In most developing countries, Lateness is a major and a continuous administrative problem among high school learners (Egbule, 2004; Dafiaghor, 2011). The society suffers a lot as 
the children of school going age hang around the street corners, intimidating other people and stealing properties of those who are in school and other places of work. Lateness could result into poor academic achievement, disruption in class, difficulty in keeping accurate records, reduced ability to meet instructional target and damage of school reputation (ETC, 2009).

The present curriculum offers continuity and progression in pupil learning and any absence from school will adversely affect the pupils' ability to participate and benefit from the learning programme. The new National Curriculum Statement (Curriculum Assessment Statement CAPS) prescribes tight learning schedules and prescribed assessment targets- which requires efficient use of time by learners and teachers. Late coming has become antithetical to the achievement of the goals of CAPS.

Reports have shown that schools that have kept children in school, separated from their peers have been able to maintain their continuity of learning. In South Africa, the resumption time for all students is 07: $30 \mathrm{am}$, but in most cases, pupils are seen or observed roaming the streets up until 9:00 am. Recently in Western Cape, the Department of Education sought the assistance of uniformed police men to patrol and possibly arrest students who were late and seen roaming about the streets (E-news, 2012). Also, a report by one of the students from Kwa - Zulu Natal province in South Africa, suggested that students should be allowed to start school very late in the morning. The students argued that if school kids are allowed to start at least an hour later, the attendance would improve, as well as grades and attitudes. The student's perception and experience of school is important in any approach for promoting good attendance. However, for a positive relationship to prevail within the school system which will ultimately lead to good output, there is a need to identify causes of lateness in high schools.

The aim of this study is to investigate different causes of late coming among high school students' especially in schools located in the township, the study focuses on the schools located within Shoshanguve. Questions were asked on the causes of late-coming from both learners, educators, principals as well as other administrative officials of the school.

\section{LITERATURE REVIEW}

Several factors have been identified in different literatures as some of the reasons why students come late to school. Chiu Mochi (1993) identified factors such as age, family commitments, change of jobs on the part of parents, health problems as some of the factors that may affect late - coming among high school students. Okwelle (2003) noted among other factors that, learner may develop negative attitude towards school resulting in late coming or poor attendance because of non - employment of school leavers, repetition of class and insecurity.

In a separate study, Alio (2003) highlighted social status and educational level of parent as factors that may influence school attendance and late coming. The study further pointed out that, geographical location of school, student's attitude towards the first subject of the day and inadequate supervision of student's activities by teachers and parents and poor teaching methods among others may also affect lateness on the part of students.

The report of Okpukpara and Chukkwuone (2007) identified the role of gender in child schooling. From the study, female headed household have higher attendance in schools whereas educated fathers are more likely to have strong impact in increasing the probability of child school attendance than mothers. Emore (2005) reported that lateness is common among female students than male students. This may be due to their involvement in domestic activities. The study further pointed to school location as one of the major causes of lateness among high school learners.

\section{SIGNIFICANCE OF THE STUDY}

Coming late to school is a growing concern and it has become increasingly difficult to eradicate. Academic performance appears to be determined by a combination of internal and external factors in the life of a learner, the influence of and impact from which fluctuate often and substantially. To date, few studies have been done to evaluate the causes of late coming among high school learners in South Africa, this study will assess the complex nature of lateness in high schools located around Shoshanguve with a view to providing necessary suggestion that may assist in alleviating the menace of late coming in high schools.

\section{RESEARCH GAP}

From the literatures cited above, much attention has been given to absenteeism, with little or no attention to lateness. However, absenteeism cannot be substituted for late - coming, the latter means partial absence for a few hours or period in a day and the former refers to total absence for a particular lesson or in a day. However, absenteeism can be 'partial' meaning that the students may be absent for part of the day or missing out on some 
periods (Moseki, 2004) or 'full' where the student is absent for an entire day (Moseki, 2004). In South Africa, much work has been dedicated to student's absenteeism in schools which in context literally means that a learner is not at school for the entire day (Mashiane, 1997; Whitney, 1998; Moseki, 2004).

\section{CONCEPTUALIZATION}

Literally, the term "late coming" implies a situation where an individual arrives after the proper, scheduled or usual time (Oxford Advanced Learners Dictionary, 2010). It could also be seen as a term used to describe people who failed to show up on the agreed time (Lauby, 2009). In some instances, lateness may seem synonymous with "tardiness", which implies being slow to act or slow to respond, thus not meeting up with proper or usual timing (Breeze et al., 2010). Lateness can be seen as a "less severe" form of withdrawal that eventually escalates into the "more severe" forms of absenteeism and turnover (Koslowsky et al., 1997). Late coming is therefore viewed as a violation of the principle of punctuality. In most cases, when condoned, it breeds a bad habit and an attitude detrimental to success in numerous enterprises in life.

Lauby (2009) defined late coming as inability of an individual or group of people to arrive at an agreed venue at the agreed time. Late-coming to school is an act of arriving at school after the official hour of commencement of the days learning activities. According to the official time table for schools, lessons commences by 7:45am, however, there are other activities that take place before the commencement of lessons, which learners are expected to participate (assembly and registration). This therefore means that all students are expected to be in school before 7:45am, in order to participate in these important activities. A situation where students do not attend these prelesson activities and are not present at the commencement of the first period is considered as late-coming to school.

From literature, much emphasis was placed on school absenteeism with little attention on lateness in schools. With absenteeism, it could either be in the form of authorised and unauthorised absenteeism (Thambirajah et al., 2008; Reid, 2005). Authorised absenteeism refers to the situation where a prior approval has been sought from the school principal with consultation from the parents while unauthorised absenteeism on the other hand refers to a situation where permission to be absent or late for the class was never granted (Whitney, 1998). From the foregoing, the authorised absenteeism involves the cooperation or good working relationship between the learner's family and the school authority. However, lateness may connote partial absence for some minutes for a particular lesson or non - arrival on time for classes.

Lateness has been recognized as having motivational antecedents. Theoretically, it is classified into three dimensions: chronic, unavoidable and avoidable. Chronic lateness is a response to a bad environment and with students dislike by mates. Relevant antecedents to chronic lateness among students in high school could be level of commitment to school and lack of satisfaction. Avoidable lateness (stable periodic lateness) occurs when student's thinks they have better or more important activities to do than arrive on time for a particular lesson or class and in most cases this happens with mathematics classes (Sims, 2002). Finally, unavoidable lateness is due to factors beyond the students' control, such as transport problems, bad weather, illness and accident (ShapiraLishchinsky, 2007).

Lateness in most instances is usually triggered by underlying factors such as laziness, tardiness and laxity (Peretomode, 1991). Late-coming can be classified into three dimensions: chronic, unavoidable and avoidable. Chronic lateness is a response to a bad environment and in the case of students, this may be as a result of lack of interest in the school, the first subject of the day or dislike by mates. Relevant antecedents to chronic lateness among students in high school could be commitment to school and satisfaction (Sims, 2002). Avoidable lateness (stable periodic lateness) occurs when student's thinks they have better or more important activities to do than arrive on time for a particular lesson or class and in most cases this happens with mathematics classes. Finally, unavoidable lateness is due to factors beyond the student's control, such as transport problems, bad weather, illness and accident (Shapira-Lishchinsky, 2007).

Late coming poses the most problem to school administrators anywhere in the world (Lauby, 2009). It is probably the most annoying breach of rules of attendance which the school officials will have to deal with on a daily basis (Robinson and Bennett, 1995; Lauby, 2009). One of the major impacts of late coming to school is the disturbance in the flow of lecture or discussion and distraction on other students (Nakpodia and Dafiaghor, 2011). The study by Nakopodia and Dafiaghor (2011) further reported that late coming to school may also impede learning and generally erode class morale especially if left unchecked. The habit can become chronic and spread throughout the class, this is why the school places a high emphasis on punctuality. In most cases, a teacher who teaches the first period is forced to teach only a percentage of learners, while those who are absent will not be able to understand the work that they have missed (Holbert and Stark, 2002).

However, it is probably not correct to say that late coming is never justifiable, there are few school officials who will deny that late coming is generally un-justifiable and that it could be eliminated by pupil if he wished and if the right attitude prevailed in the home. In some instances, parents may consciously and willingly permit their 
children to arrive late to school many times. From the foregoing, it is obvious therefore that late coming could be seen as a system of network breakdown (Peretomode, 1991) a situation of not meeting up with the established systems.

\section{RESEARCH DESIGH AND METHODOLOGY}

The study was carried out in Shoshanguve; a township situated about $25 \mathrm{~km}$ north of Pretoria now known as Tshwane, in Gauteng province, South Africa.

\section{Approaches}

A qualitative approach was used to conduct this research project. The strength of qualitative research revolved around its ability to provide complex textual descriptions of how people experience a given research issue. It provided information about the human side of an issue. This included the contradictory behaviours, beliefs, opinions, emotions, and relationships of individuals. (Neumann, 2000).

Data was collected through literature review, an examination of learner's attendance record, observation as well as interviews with the learners, some educators and the principal of each school. The interviews conducted gave a representative picture and provided a basis for interpretation. The interviewer ensured that all questions were answered and the interviewer's observations in terms of the quality of the interview and characteristics of respondents were included in the interview schedule. The participants were both males and females from grades 10 to 12 and grades 7 to 9 in the junior secondary schools. The participants were observed and interviewed in their natural setting. Their viewpoints, facts and insight into the problem were useful for this study. The research questions focused more on the causes of late-coming to school among high school students.

\section{Study Design}

The study design involved a multiple case study research. Multiple-case studies design allowed the researcher to explore the phenomena under study, through the use of a replication strategy (Yin, 2004). The conclusions from one case were compared and contrasted with the results from the other cases. Two types of selections were used; the literal replication where the cases selected were similar and the predicted results were similar too. The theoretical replication where the cases were selected based on the assumption that they will produce contradictory results (Zach, 2006).

\section{Sampling}

In this research, only samples (that is, a subset) of a population were selected for the study. The research objectives and the characteristics of the study population (such as size and diversity) determined which and the number of students that were selected. The sampling method in this research was purposive sampling. From each of the selected schools, two teachers each representing each grade (10,11 and 12) and (7 to 9) in junior high schools were chosen and interviewed. Students for this study were given by the school principals because of they have been known as perpetual late comers.

Interviews for educators and principals revealed the perceived effect of late coming on teaching, class morale, educator's morale and effects among others. To understand the reasons for coming late on the part of students, the targeted population were students in grades 10,11 and 12 as this forms the core of the adult students within the high school system in South Africa. Students from the grades mentioned were interviewed from six different schools within Soshanguve; a total numbers of eighty students, twelve educators and six principals were used for this study. All interviews were audio recorded, so that the facts of the interviewees were captured verbatim.

\section{Data Analysis}

From the present research study, we report on the result of the interviews and the result was analysed descriptively using a qualitative coding method. Strauss and Corbin (1990) explained that there are three types of coding namely: open, axial and selective coding. Similar responses from students were grouped together to form categories which were deduced from the questions asked the students (Open coding). Connections and relationships between the categories were also carried out by looking at the various conditions and consequences of their actions (Axial coding). Information received from different categories were related and validated in order to establish relationship and see if any common reason could not be established as the major factor for coming late to schools (Selective coding).

\section{Ethical considerations}

An approved consent letter of schools to participate in the research was obtained from the District and Head office of the Gauteng Department of Education. A letter of consent was also sent to the principal of each of the 
selected high schools for their permission to conduct the study. Prior to the interview, the researcher asked permission from the respondents before using a tape recorder, the way in which the tape recorder will be used, stored as well as destroyed later was explained to them.

Anonymity was also ensured before the start of the interview. During the induction and passing information for the informed consent, participants were told about their freedom to withdraw if they were no more enjoying the interview. The respondents were also informed about the plans for retaining the data, and for providing access to other researchers during that period; confidentiality was consistent throughout the period of the interview. The students were observed before the start of the class and after the break period, the attendance register for the day was used. The interview was conducted immediately after the closing of the school for the day in order not to disrupt the normal class.

The students were briefed of the purpose of the research and they were informed that they were free not to participate in the study if they so wished but they all consented to participate. The students were interviewed individually without mentioning their names and identity numbers. The interview lasted for more than 10 minutes.

\section{FINDINGS}

\section{LEARNERS RESPONSES ON:}

\section{Factors causing lateness to school}

The present study revealed several factors that may be responsible for lateness to school among the high school learners. The causes were divided into various categories such as activities the student engaged with before sleeping at nights, the time the students normally wake - up every day before going to school, reasons for getting to school late every day, their general perceptions about school and the frequency of their lateness to school within the term.

\section{Activities before sleeping at nights and wake up time in the morning}

The findings revealed that most of the learners normally engaged in watching television or playing games till midnight. Some of the learners interviewed also complained that they normally receive lots of homework which must be submitted the next day. Apart from the school homework, catering and attending to house chores may make it difficult for some female learners to sleep early. Most of the female learners complained about lots of house chores which they have to finish before attending to their school works and this made them go to bed late. The literature revealed that in some instances, parents are unconsciously and unwillingly responsible for their children late arrivals to school many times. In situations where the house chores overwhelmed the children and eventually makes them tired before going to bed, may affect the time they wake up the next day. The learners responded in various ways:

Learner A52 said:

"I have lots of home work to do and my mum still expects me to wash dishes before sleeping"

Learner A15 lamented:

"I am the eldest in the family and I have to do everything in the house because my mummy usually come back late from work and my father is not staying with us"

Learner A39 responded by saying that, "our teachers are wicked they know we can never finish our homework on time, hence we have to go to bed very late at nights".

Learner A70 also said:

"We get homework from all the subjects. How can you sleep on time?"

The general feelings of the learners showed that the assignment given to the learners may be overwhelming hence they may be delayed from sleeping on time at nights.

The other reason according to the findings of this study might be the idea of watching television and playing games till late at nights by some of the learners. From those interviewed, this situation normally occurs on Sunday evenings where the movies advertised may be interesting and the learners were willing to watch the movie.

Learner A10 said:

"I came late to school this morning because I slept late last night".

Learner A10 provided reasons for coming late, "I love watching late night movies especially when it is an action packed movie". 
Learner A32 from a different school also mentioned similar reasons for sleeping late at nights.

\section{Learner's responses on activities before going to school.}

The study revealed that most of the female learners engage in many activities before going to school. The report of Emore (2005) showed that lateness is common among female students than male students. This may be due to their involvement in domestic activities.

Learner A4 said:

"I have to finish my house chores and take my baby sister to pre-school before going to school".

Learner A12 explained:

"My mum had been sick for a long time now and nobody is helping us, I have to wake up early to prepare her for bath and food and also prepare my siblings for school before I can come to school".

Learner A35 lamented:

"I live with my grandmother, she is very old and cannot do anything again, she relied on me to do everything in the house and even prepare her lunch before going to school".

However, from the study, it was further gathered that some of the learners do not have any good reason for coming late to school. The idea of staying late at nights to watch TV or play games were not good reasons for coming late to schools. For example, idleness or laziness may be reasons why some learners come late to school.

Learner A18 said:

"I don't do anything at home apart from washing myself and eating my breakfast".

Learner A12 said:

"There is this movie I always see in the morning and I have been following it for months now, I can't do but see it in the morning before I go to school".

This study further revealed that many of the learners only attend to their assignments in the morning instead of going through it at nights and thereby leaving home late for school.

Learner A6 explained:

"I normally get home tired and I have to rest, so I do my assignment in the morning before going to school".

Learner A1 said:

"I can't finish my homework before I sleep, so I have to complete it in the morning before I go school".

Learner A42 said:

"I am a slow eater and my mother always insisted I finish my food before going to school".

Learner A12 complained:

"I do my hair in the morning before going to school".

Learner A49 admits:

"I am always lazy to iron my cloth at night, so I usually iron in the morning".

\section{Learner's responses on their perception about the time school open for the day.}

All the principals from the six schools under study stated that the first subject for the day must start by 7:45 am and the learners must all be in school by 7:30 am. However, most of the learners lamented bitterly about this, many of them said the time was too early and would prefer a change of time.

Learner A7 lamented: 
"7:30 is too early, we have many things to do in the morning before going to school, it would be better if the time could be changed to 8:00 and the first lesson to 8:30am".

"I don't mind 9:00am", said learner A29.

Learner A56 said:

"Why can't they just change the time to accommodate some of us who does not come late deliberately".

"Many of us will do better if they can just change the time", said learner A45.

Despite the fact that most of the learners would prefer a change in the time school resumes for the day, some of them admitted that the educational board knew what they were doing when they set the time for 7:45 am, some of them agreed that it was for their own benefit, this allowed them to assimilate easily since it was still very early and that was why they normally had their important subject like mathematics and science in the morning.

Learner A23 argued that:

"It is better to start school early in the morning when your memory is still fresh, so 7:30 am is fine by me, I just need to make effort and come early".

Learner A48 responded by defending the time school resumes:

"If some learners can come early, it means the time is not too early"

\section{Effect of the first subject of the day and the teacher that teaches the subject.}

The present study revealed that the teachers who normally teaches the first lesson only teaches few learners because many of the learners were late for the first lesson and would be serving their punishment outside the gate while the lesson was going on. The study also revealed that some of the learners deliberately come late on a particular day either because of the first subject of the day or the teacher (personality) teaching the subject.

Learner A39 said:

"My first subject today is boring, the teacher only read to us and I have my book, she doesn't know how to explain".

Learner A59 lamented:

"The teacher always teases me and make fun of me in front of other student's, I don't want to attend his class".

Learner A72 said:

"The first subject today is too difficult for me to understand and the teacher does not know how to teach, I prefer my last year teacher".

Learner A30 lamented:

"I am not comfortable with that teacher, he always insults me in class because he once saw me with my girlfriend".

"Many of us have complained to the principal about the teacher, she always come late to school, why should I be here early?" reported by learner A5.

According to some of the learners, some teachers comes late to school, while some uses abusive language on the learners, some of the teachers also take an advantage when the principal is not around, they sit in the staff room and discuss instead of going to classes.

Learner A54 lamented:

"The teacher always said that I will end up like my grandmother who relies on grants, so I don't want to attend her class".

\section{The effect of season on coming late to school.}

The interviews and observation were carried out between March and June 2013 as mentioned earlier, In South Africa, this period of the month is always cold, the weather start to change in March and get colder till the end of July and sometimes till early august. The study revealed that during this period, learners normally find it difficult 
to wake up early and since there are no changes in the time school resume, almost all the learners come late to school during this period and lamented bitterly about the weather.

Learner A13 lamented:

"It is too dark in the morning and I can't start walking to school when it is dark".

"It is too cold in winter, I get to school frozen and can't listen and concentrate" lamented learner A48.

Learner A71 said:

"It is very cold in the morning, so I am lazy to wake up".

"It is very dark and not safe for me to come early" lamented learner A29.

The responses of almost all the learners showed that the weather may not be conducive for them during winter and this is why all the school visited had higher numbers of late comers during this period.

\section{The effect of distance.}

Distance has been identified as one of the key factors that have contributed to late coming. Some of the learners interviewed came from far and find it difficult to get to school early. Only one of the schools visited were fortunate to have school buses that transport the learners to school in the morning and back home in the afternoon, the other schools did not have this opportunity so the learners either come to school by walking or come in a taxi, very few of the learners were dropped by their parents in the morning. The study revealed that some of the learners do not have choice because there were no other schools closer to them, than the ones they were attending while some of them had choices to attend a school nearby but their parents preferred this school because of their academic performance or infrastructional materials and the principal of the school had little or no influence on that.

Learner A3 complained:

"My home is too far from school and I don't have money for taxi".

"I walk about $1 \mathrm{hr} 30 \mathrm{~min}$ to school every day, even if I wake up early, I will still get to school late" lamented learner A54.

Learner A23 said:

"My house is far, the road is bushy and unsafe and there is no other school than this"

"If the school can provide school bus for us, we will come early because we don't have money for transport" commented some of the learners.

On the other hand, some learners stayed very close to school and they still get to school late. When asked their reasons for lateness, they could not say anything other than "I woke up late" or "My sister did not wake me up". To these ones, it can be concluded that late coming had become their habit and this needs serious attention.

I also noticed from the school with school buses that some of the learners still come late to school and when asked, some of them said that the driver of the buses were impatient and will not wait for them, so they had to come on their own either by foot or taxi depending on the distance.

Learner A36 lamented:

"The driver saw me coming and just zoomed off, he always does that to me, I guess he hates me".

"That driver is wicked, he will see us running but will not wait and come to school to tell the principal lies" lamented learner A32.

Nevertheless, some of them agreed that it was their fault that the school bus did not take them to school.

Learner A40 agreed:

"I did not notice that my alarm was set wrongly, so I woke up late"

Learner A34 said:

"I was too tired to wake up because of the weather". 


\section{SUMMARY OF THE FINDINGS}

The findings gathered from the interview conducted with the learners revealed that most learners were aware of the dangers of coming to school late but could not help in some cases. Most of the learners felt that the resumption time for school is way too early because they engaged in different activities before they sleep at night and early in the morning before they go to school.

It appears that lack of transportation and geographic distance is another reason that made late coming to school seems like an issue that could not be solved. Most of the learners lived far from school which posed a lot of difficulties for them especially during winter.

In some cases, it seems parents lacked control over their children behaviour. Some of the learners were left alone to do whatever seems good to them; most learners watched movies till late and end up waking up late in the morning.

Discouragement is another issue for concern; some learners were discouraged from attending a particular class because of the teacher that teaches the subject. Some felt the teacher hate them and would decide to come late to school whenever that particular teacher would be teacher early in the morning.

Learners were sometimes influenced by their friend, most of the learners walked to school in peers, chatting and dragging their feet on their way to school and thereby get to school late. Some learners went as far as visiting their friends in other schools in the morning before going to school.

In summary, the investigation showed that most of the problems associated with late coming were beyond the learners control while in some cases, learners' needs to discipline themselves and focus on the more important things.

\section{DISCUSSION}

The study established that late coming is a serious problem in all the schools used for this study. Learners usually arrived at about ten - fifteen minutes after the commencement of the first lesson. The key problem that emerged from the study was the issue of sleeping very late at nights as a result of watching television till midnight or getting too much involved in house chores especially on the part of the female students.

Lack of proper monitoring on the part of the parents played a major role in coming late to school from some of the students. Also, the effect of divided household contributed greatly in coming late to schools. In most of the divided household, learners assumed the responsibility of becoming parents at a very tender age when they were supposed to be supervised.

Good leadership is a major contributor for the success and improvement of the school (Borman, 2000; Harris et al, 2003). Good leadership will assist greatly in managing the tensions and problems that might be directly facing the school.

The attitudes of some educators and the first subject of the day also contributed immensely to late coming from some of the learners. The learners believed that certain subjects are too difficult and should not be used as first class for the day. Some learners argued that some of the educators do not know how to teach such subjects; hence, they believed it is a waste of time arriving very early especially when such subjects are the first lesson of the day. This tendency has greatly affected the academic performance of these learners.

The impact of peer pressure and weather could not be over emphasized. Friends play a significant role in coming late to schools. If all the students can get prepared on time, there will be no reason for a student to come late since all of them get ready early enough to go to school.

Disciplinary measures seem not to be effective as learners are well aware that no corporal punishment should be meted out to them, hence laxity in coming early to school. Principals and educators seem to be tired because there is no strict rule that empowers them to punish students that come to school late.

\section{CONCLUSION AND RECOMMENDATIONS}

Late coming has posed a lot of challenges among high school learners. Among this is the academic performance of the learner which was a cause for concern. The result of this study showed that parents have a lot to do in the training of their children as this may have positive or negative impacts as shown from the study. The United Nation Declaration of the Right of the Child (1959) laid more emphasis on the fact that child interest for education lies first in the hand of the parents. It was evident that insufficient sleep at night did not only cause late coming to school, learners also lose focus during the day, parents therefore needs to monitor their children sleep and wake up time. 
The study also confirmed the influence of teacher's behaviour and attitude in the life of the learners. In most cases, learners put more trust in their teachers than parents, they see the teacher as a role model and thus follow their examples, and teachers therefore, need to come to the aid of the learners by using different techniques such as listening to them and telling them the impact of their misbehaviour on themselves and others. It is also important to keep an eye on the learners especially those of adolescent age; this will enable the teacher to recognise their area of needs. Teachers' punctuality, regular school attendance and well prepared lesson will also motivate the learners to come to school early.

Poor school management was another cause for concern. Dean et al (1994) indicated that principals' success in school management depended very largely on their sound relationship with teachers and effective communications among all stake holders, this is very important for the smooth running of the school.

Parents needs to take charge of their responsibilities, this will enable them to understand that everything that happens to their children at school could likely be the result of the learning environment provided for them at home.

Learners need to know and understand what is at stake, this will help them to take responsibility on their own education by coming to school early, but the fact remains that learners cannot do this on their own, they need adequate support from all stake holders, all the academic and non-academic staff including the administration should strive to leave a positive impact on the learners.

No problem related to children should be seen as a problem without a solution. We make it a problem if we fail to understand and resolve them.

\section{REFERENCES}

Alio, B.C. (2003). Obstacles to effective secondary school mathematics in Education: The Challemge of Mathematics Educators. Journal of Research Development NARD, 1, pp. 66-71.

Borman, G.D. (2000). Four models of school improvement. Success and Challenges in Reforming low- performing, High Poverty Title 1 Schools. Baltimore: John Hopkins University, Centre for Research into Education of Students Placed at High Risk.

Breeze, S., Markey, C. and Woll, V. (2010). "How to be punctual". [online] Available at: http://www.wikihow.com/Be-Punctual (Accessed 23 September 2012).

Chiu, M. (1993). A study of factors affecting attendance at adult education short courses in China. Study at Home Communication Science, 3, pp. 45-49.

Dafiaghor, F. (2011). Lateness: A major problem confronting administrators in Delta State Nigeria. International NGO Journal, 6, pp 166-169.

Dean, J.W. and Bowen, D.E. (1994). Management theory and total quality: Improving research and practice through theory development. Academy of Management Review. 19(3), pp. 392-418.

Declaration of the Rights of the Child A/RES/1386(XIV) (20 November 1959). Retrieved 22 Aug. 2008.

Egbule, J.F. (2004). Readings in Educational psychology. Owerri: Barlos Publisher.

Emore. C. (2005). Causes of students lateness to school in Uvwie LGA of Delta State. Unpublished Postgraduate Diploma in Education Project, Delta State Univeristy, Abraka, Nigeria.

E- News (2012). Information from e- news on 24/04/2012.

Employment and Training Corporation (ETC) (2009). Attendance and punctuality policy. Policy Workshop Abuja, Nigeria.

Harris, A., Muijs, D., Chapman, C., Stoll, L. and Russ, J. (2003). Improving schools in disadvantaged areas - A Review of the Research Evidence. DFES Moorfoot.

Henning, E., van Rensburg, W. and Smit, B. (2004). Finding your way in Qualitative Research. Pretoria: Van Schaik Publishers.

Holbert T., Wu, L. and Stark, M. (2002). School Attendance Initiatives (S AI): The first three years 1998/9 - 2000/1, Third Annual Evaluation Report, Oregon Department of Human Services.

Koslowsky, M., Sagie A., Krausz M. and Dolman-Singer, A.D. (1997.) Correlates of employee lateness: Some theoretical considerations. Journal of Applied Psychology, 82, pp. 79-88.

Lauby, S. (2009). Attendance and Punctuality. Available at: http://www.hrbartender.com/2009/comp/attendancepunctuality/ (Accessed 23 September 2010)

Mashiane, R.T. (1997). Truancy in black schools: the role of teachers. Unpublished M.Ed. dissertation, Rand Afrikaans University, South Africa.

Moseki, M. (2004). The nature of truancy and the lifeworld of truants in secondary schools. Unpublished D.Ed. Thesis. University of South Africa.

Nakpodia, E.D. and Dafiaghor, F.K. (2011). Lateness: A major problem confronting school administrators in Delta State, Nigeria. International Journal of Science and Technology Education Research, 2, pp. 58-61. 
Neumann, W.L. (2000). Social research methods: Qualitative and Quantitative approaches. USA: Pearson Education Inc.

Oghuvbu, E.P. (2012). Attendance and academic performance of students in secondary schools: A correlational approach. Study at Home Communication Science, 4, pp. 21-25.

Okwelle, P.C. (2003). Strategies for eliminating wastages in vocational and technical education for sustainable technological development in Nigeria. Journal of Research in Education, 4, pp. 30-36.

Okpukpara, B.C. and Chukkwuone, N.E. (2007). Child schooling in Nigeria: The role of Gender in Urban, Rural North and South Nigeria. A study on School attendance performance in Nigeria founded by African Research Consortium, Abuja, pp 1-6.

Onouwodeke, M. A. (1995). The management of students learning problems. Delta Journal of Educational Development, Abraka, 2, pp. 81-90.

Oxford Advanced Learners Dictionary of Current English 8th ed. (2010). Oxford: University Press.

Peretomode, V.F. (1991). Educational Administration: Applied concepts and theoretical perspectives for students and practitioners. Lagos: Joja Educational Research and Publishers.

Phurutse, M.C. (2005). Factors affecting teaching and learning in South African Public Schools. Cape Twon: Human Science Research Council Press.

Reid, K. (2005). The causes, views and traits of school absenteeism and truancy. Research in Education, 74, pp. 5984.

Robinson, S.L. and Benett, R.J. (1995). A typology of deviant work behaviours; A multidimensional scale study. Academy of Management Journal, 38, pp. 555-572.

Shapira-Lishchinsky, L. (2007). Israeli teachers' perceptions of Lateness: A Gender Comparison. Sex Roles: $A$ Journal of Research into Human Behaviour, 43, pp. 82-78.

Sims, R.L. (2002). Ethical rule breaking by employees. A test of social bonding theory. Journal of Business Ethics, 40, pp. 101-109.

Strauss, L. and Corbin, J. (1990). Grounded theory procedures and techniques, Canons and evaluation criteria. In Zeithchrift fur Soziologie, 19. Jg, S. $418 \mathrm{ff}$.

Thambirajah, M.S., Grandison, K.J. and De-Hayes, L. (2008). Understanding school refusal: a handbook for professionals in education, health and social care. Jessica Kingsley: London and Philadephia.

Whitney, B. (1998). The truth about truancy. London Publishers, pp. 23-26.

Yin, R.K. (2004). Case study methods. Cosmos Corporation, Revised draft. Thousand Oaks, CA: Sage Publication.

Zach, L. (2006). Using a multiple case study design to investigate information -seeking behaviour of arts administrators. Library Trends, 5, pp. 4-21. 